\title{
THE BULGARIAN HEALTH CARE SYSTEM PRACTICAL RESEARCH ON THE USEFULLNESS OF THE PERFORMANCE MEASUREMENT SYSTEM
}

\author{
Venelin Terziev ${ }^{\mathbf{1}}$ and Stoyanka Petkova - Georgieva ${ }^{2}$ \\ ${ }^{1}$ Full Member of the Russian Academy of Natural History, Professor, Eng., D.Sc. (National \\ Security), D.Sc. (Economics), D.Sc. (Social Activities), Ph.D., Russian Academy of Natural History, \\ Moscow, Russia, Vasil Levski National Military University, Veliko Tarnovo, Bulgaria University of \\ Rousse, Rousse, Bulgaria, terziev@skmat.com \\ ${ }^{2}$ Associate Professor, Ph.D., University „Prof. d-r Assen Zlatarov” - Bourgas, Bulgaria, \\ s.p.petkova@gmail.com
}

\begin{abstract}
The advantages and disadvantages of the decentralization organizational management structures are very important to be investigated because of their impact on the competitiveness on micro and macro level. In the present study are published the results from a seven years research among Bulgarian health care managers. The basic idea was to investigate how the practical implementation of the performance measurement system is a very powerful instrument to increase the competitiveness of the health care subdivisional unit even though if it is an organized system with a very decentralizated structure.
\end{abstract}

Keywords: competitiveness, impact, level of decentralization, Bulgarian health care system.

\section{INTRODUCTION}

The system of performance measures (PMS) is a significant and traditional instrument for increasing the management efficiency of a business organization with a lot of sub-divisional structures on many levels of decentralization. Their use can essentially be traced back to two problem areas. Using the existing data without focusing on management bottlenecks demands a manipulation of large amount of numbers with little useful information, thence with restricted practical use. Another disadvantage is that they usually operate with valuable and based on past experience quantities.

In the contemporary literature a lot of "new" versions of systems of performance measures have been suggested which addressed these deficiencies. Depending on what conception the PMS is based, they can be classified to balanced and focused. The balanced scorecard is the usual representative in the first group and the system of selective performance measures is the representative of the second (Bouwens, Abernethy, 2000).

The design of PMS for the strategic control systems should be based on the return of management (ROM) as a maximization criterion and manager's time and attention is a scarce resource, which has to be optimized (Terziev, Petkova- Georgieva, 2019a). This measure shows the return of investments in scarce resources (e.g. manager's time and attention). ROM is not a quantitative amount, so the manager as an intuitive estimate can only determine it. As a control quantity it can indicate directions, but not definite targets.

If we apply the ideas behind ROM to performance measure systems, it would be advisable to differentiate 
between diagnostic and interactive PMS (Terziev, Petkova- Georgieva, 2019). Both types of performance measure systems described are needed for successfully controlling of the business. For this reason, it is necessary to develop an improved active PMS which passes at two basic stages. Firstly, filtration and selection only of these measures, that describe the value creation chain of an organization - the design of PMS. The second stage is focused on the leading narrow events and factors (Christie, Joye, Watts, 1993).

\section{THEORETICAL STUDY}

One of the significant problems for organizations with multidivisional structures is to establish the optimal decentralization in manager's decision making. It is obvious, that the level of decentralization influences the structure and design of PMS. Therefore, the improvement of PMS in organizations with multidivisional structure demands to be established the factors, which mostly influence the level of decentralization and the structure of PMS.

According to the Keating's and Nagar's approach (Milgrom, Roberts, 2016; Petkova - Georgieva, 2018), there are two basic determinants identified as important to organization design choices, namely, subunit interdependencies and knowledge transfer costs.

The purpose of this study is to assess the impact of defined above factors, both on decentralization and on structure of PMS. For this reason, we test our predictions with a simultaneous equation model that captures the level of decentralization and the structure of PMS.

Because of the restrictions of the paper amount we will only present the first step of conducted research. The aim of the paper is to summarize theoretical interdependencies among the determinants that influence the level of the decentralization and the structure of PMS and also to present attained results of the carried-out investigation.

Theory and earlier evidence suggest that decisions relating to decentralization and PMS choices are made simultaneously and that these choices are influenced by a number of exogenous factors. The impact of interdependencies among subunits and cost of transferring knowledge on these choices is discussed in turn.

\section{- Interdependencies}

Interdependencies among organizational subunits vary along a continuum. At one end of the continuum subunits operate autonomously where the only form of interdependence is with corporate services, to the other end where subunits have reciprocal interdependencies. This is where subunits are required to trade their intermediate products with each other. In other words, the demand functions of the subunits firm may be dependent or they may have joint supply and cost functions. The operating externalities created by such dependencies directly influence top health care management's decision to delegate decision rights.

Our study is based on the analytical frameworks developed by Jensen and Meckling (Keating, 1997) and Milgrom and Roberts (Simons, 2017). The model assesses choices relating to level of decentralization and two forms of subunit performance metrics, namely, aggregated performance measures (eg. profit or ROI) and disaggregated performance measures or what we refer to as specific performance measures (e.g. production expenditure, R\&D, sales revenues). The simultaneous equation model can be summarized as follows:

- $\quad$ DECEN = function (AGG, SPEC, SI, KTC).

- $A G G=$ function (DECEN, SPEC, SI, KTC).

- $\mathrm{SPEC}$ = function (DECEN, AGG, SI, KTC).

DECEN - Decentralization; AGG - Aggregated PMs; SPEC - Specific PMs; SI - Subunit Interdependencies; KTC - Knowledge Transfer Cost;

We conducted our research in Bulgarian health care facilities and hospitals (the real names of the health care organizations are confident). The necessary data for the test of the model was obtained from a survey of 78 managers from 18 divisions of the Bulgarian facilities and hospitals. We find that decentralization is positively and significantly related to knowledge transfer costs and negatively related to levels of subunit interdependencies. The use of aggregated PMs is significantly related to subunit interdependencies. However, the significance and direction of the relation depends on the nature of the interdependencies. When the actions of divisional managers influence the performance of other divisions the relationship is negative but not significant. However, we found that the use of aggregated PMs increases when the divisional manager's own performance is influenced by actions of other divisional managers. Only knowledge transfer costs and the level of decentralization influenced the use of specific PMs. Statistical information 
about the number of the Bulgarian hospitals for long-term treatment is given on Table 1.

Table 1. The number of the Bulgarian health care facilities and hospitals in 2012 - 2018.

\begin{tabular}{|c|c|c|c|c|c|c|c|c|}
\hline $\begin{array}{c}\text { BULGARIAN HOSPITALS BY } \\
\text { TYPE }\end{array}$ & 2012 & 2013 & 2014 & 2015 & 2016 & 2017 & 2018 & $\begin{array}{l}\% \text { CHANGE } \\
(2012-2018)\end{array}$ \\
\hline Multi-profile hospitals & 121 & 120 & 114 & 111 & 113 & 114 & 112 & $-7,4$ \\
\hline $\begin{array}{c}\text { Specialized hospitals for active } \\
\text { treatment }\end{array}$ & 39 & 39 & 37 & 37 & 36 & 34 & 33 & $-15,4$ \\
\hline $\begin{array}{l}\text { Specialized hospitals for long- } \\
\text { term treatment }\end{array}$ & 5 & 5 & 5 & 5 & 4 & 3 & 0 & - \\
\hline $\begin{array}{l}\text { Specialized hospitals for long- } \\
\text { term treatment and } \\
\text { rehabilitation }\end{array}$ & 14 & 13 & 2 & 12 & 12 & 11 & 10 & $-28,6$ \\
\hline $\begin{array}{l}\text { Specialized hospitals for } \\
\text { rehabilitation }\end{array}$ & 19 & 19 & 19 & 19 & 19 & 19 & 21 & 10,5 \\
\hline Psychiatric hospitals & 12 & 12 & 12 & 12 & 12 & 12 & 12 & 0,0 \\
\hline $\begin{array}{l}\text { Hospitals for other } \\
\text { administrations }\end{array}$ & 14 & 18 & 21 & 24 & 21 & 21 & 21 & 50,0 \\
\hline $\begin{array}{l}\text { Hospitals per ownership: private } \\
\text { hospitals }\end{array}$ & 88 & 89 & 92 & 99 & 106 & 108 & 111 & 26,1 \\
\hline \multicolumn{9}{|c|}{ Former dispensary centers: } \\
\hline $\begin{array}{l}\text { - Comprehensive cancer } \\
\text { centers }\end{array}$ & 9 & 7 & 7 & 7 & 7 & 7 & 7 & $-22,2$ \\
\hline $\begin{array}{l}\text { - Centers for dermatome - } \\
\text { venereal diseases }\end{array}$ & 10 & 10 & 8 & 7 & 7 & 7 & 5 & $-50,0$ \\
\hline - Mental health centers & 12 & 12 & 12 & 12 & 12 & 12 & 12 & 0,0 \\
\hline
\end{tabular}

Sources: Bulgarian National Centre of Public Health and Analysis (BNCPHA)

* Note: A number of specialized hospitals are included in the total without featuring in the categories, listed in Table 1.

The existence of operating externalities implies that there are benefits to be gained by coordinating the activities of the subunits. When local health care managers are delegated decision rights, they will optimize their own subunit's profit rather than consider the impact of their decisions on other units. Hence, ceteris paribus, the cost associated with decentralization will increase as operating dependencies increase. Top management will attempt to minimize the opportunity for suboptimal decision making by centralizing decision making. In other words, centralization will be the least cost option when interdependencies are high. Interdependencies will also significantly influence the design and use of PMSs (Todorov, 2018a; Todorov, 2015a).

However, the impact of interdependencies on the use of PMSs is not due to the effect of operating externalities, as such. Rather, it is the influence that interdependencies have on the behavior of subunit managers when performance is measured based on metrics that are influenced by actions of other subunits (Jensen, Meckling, 1992). They argued that firm level profit would be superior to the subunit profit measure due to the "noise" created by the activities performed in other subunits. Not only does the subunit profit measure become less informative in assessing managerial performance, superiors will also use firm profit to encourage subunit managers to co-operate. In contrast, when interdependencies are low, subunit profit will 
become increasingly important.

\section{- Hypotheses}

Table 2 and the following hypotheses summarize the above discussion:

$\mathrm{H} 1$ : The level of decentralization decreases as the subunit operating interdependencies increase and increases as the level of subunit specific knowledge, subunit growth opportunities, size and competition increase;

H2: The use of aggregated subunit performance measures decreases when subunit interdependencies increase and increases when competition intensifies;

H3: The use of specific subunit performance measures decreases as subunit interdependencies increase and increases as subunit specific knowledge increases and competition intensifies.

Table 2. Main effects investigated in this research.

\begin{tabular}{|c|c|c|c|}
\hline $\begin{array}{c}\text { Factor affecting } \\
\text { organizational design }\end{array}$ & $\begin{array}{l}\text { 2. Decentrali } \\
\text { zation level } \\
\text { (DECEN) }\end{array}$ & $\begin{array}{c}\text { Own-level } \\
\text { performance } \\
\text { measure } \\
\text { (AGG) }\end{array}$ & $\begin{array}{c}\text { Specific } \\
\text { performance } \\
\text { measure } \\
\text { (SPEC) }\end{array}$ \\
\hline \multicolumn{4}{|l|}{ 3. Knowledge Transfer Costs } \\
\hline *Specific Knowledge (SK) & + & - & + \\
\hline \multicolumn{4}{|l|}{ *Environmental Conditions } \\
\hline -Growth & + & & \\
\hline -Size & + & & \\
\hline -Competition & + & + & + \\
\hline 4. Subunit interdependencies & - & - & - \\
\hline
\end{tabular}

\section{INVESTIGATION RESULTS}

Our sample included divisions that were defined as subunits that report directly to the Chief Executive Officer (CEO) or Chief Operating Officer (COO) of the business organization from The Bulgarian health care system. The used survey instruments are checklists. Summary statistics for each variable are presented in Table 3.

Table 3. Results from the research study.

\begin{tabular}{|c|c|c|c|c|c|c|}
\hline \multirow{2}{*}{$\begin{array}{c}\text { Independent } \\
\text { Variables }\end{array}$} & \multicolumn{5}{|c|}{ Parameters' significance } \\
\cline { 2 - 7 } & P.S. & DECEN & P.S. & AGG & P.S. & SPEC \\
\hline Constanta & & $\begin{array}{c}0.329 \\
(1.034)\end{array}$ & & $\begin{array}{c}15.178 \\
(24.496)\end{array}$ & & $\begin{array}{c}84.098 \\
(19.416)[1 \%]\end{array}$ \\
\hline AGG & + & $\begin{array}{c}0.006 \\
(0.003)[10 \%]\end{array}$ & & & $?$ & $\begin{array}{c}0.002 \\
(0.105)\end{array}$ \\
\hline SPEC & $?$ & $\begin{array}{c}-0.008 \\
(0.005)[10 \%]\end{array}$ & $?$ & $\begin{array}{c}0.069 \\
(0.142)\end{array}$ & & \\
\hline
\end{tabular}


IJASOS- International E-Journal of Advances in Social Sciences, Vol. V, Issue 15, December 2019

\begin{tabular}{|c|c|c|c|c|c|c|}
\hline DECEN & & & + & $\begin{array}{c}8.499 \\
(3.508) \text { [5\%] }\end{array}$ & $?$ & $\begin{array}{c}-10.218 \\
(2.895)[1 \%]\end{array}$ \\
\hline SK & + & $\begin{array}{c}0.094 \\
(0.017)[1 \%]\end{array}$ & - & $\begin{array}{l}-0.305 \\
(0.555)\end{array}$ & + & $\begin{array}{c}0.900 \\
(0.561)\end{array}$ \\
\hline SUPPLY & - & $\begin{array}{c}-0.005 \\
(0.002)[5 \%]\end{array}$ & & & & \\
\hline GROWTH & + & $\begin{array}{c}0.171(0.064) \\
{[1 \%]}\end{array}$ & & & & \\
\hline SIZE & + & $\begin{array}{c}0.086 \\
(0.046)[10 \%]\end{array}$ & & & & \\
\hline PPERF & + & $\begin{array}{l}-0.016 \\
(0.037)\end{array}$ & & & & \\
\hline IMPACT 1 & & & - & $\begin{array}{c}-3.849 \\
(1.931)[5 \%]\end{array}$ & - & $\begin{array}{c}0.850 \\
(1.685)\end{array}$ \\
\hline IMPACT2 & & & - & $\begin{array}{c}4.681 \\
(2.142) \text { [5\%] }\end{array}$ & - & $\begin{array}{l}-2.271 \\
(1.825)\end{array}$ \\
\hline RSIZE & & & + & $\begin{array}{l}-0.205 \\
(0.147)\end{array}$ & + & $\begin{array}{c}0.092 \\
(0.128)\end{array}$ \\
\hline INT_AGG & & & + & $\begin{array}{c}0.258 \\
(0.120)[5 \%]\end{array}$ & & \\
\hline COMP & + & $\begin{array}{l}-0.020 \\
(0.023)\end{array}$ & + & $\begin{array}{l}-0.411 \\
(0.695)\end{array}$ & + & $\begin{array}{l}-0.038 \\
(0.596)\end{array}$ \\
\hline CPERF & & & & & - & $\begin{array}{c}-2.728 \\
(1.375)[10 \%]\end{array}$ \\
\hline INT_SPEC & & & & & + & $\begin{array}{c}0.075 \\
(0.111)\end{array}$ \\
\hline $\mathrm{R}^{2}$ & & $53.80 \%$ & & $16.57 \%$ & & $17.44 \%$ \\
\hline $\mathrm{F}$ & & 9.150 & & 2.390 & & 2.356 \\
\hline Probability. (F) & & 0.0001 & & 0.0147 & & 0.0139 \\
\hline
\end{tabular}

- DECEN - summary statistics for decentralization;

- AGG - use of own-level aggregated performance measures;

- SPEC - use of specific measures;

- SK - specific knowledge; 
- SUPPLY - operating interdependencies;

- GROWTH - growth opportunities;

- SIZE - size of the unit;

- PPERF - past performance;

- IMPACT1- impact of unit on performance of other units in firm;

- IMPACT2 - impact of other units in firm on performance of own unit;

- RSIZE - relative size of unit in firm;

- COMP - degree of competition;

- INT_AGG - intensity of own-level aggregated measures;

- INT_SPEC - intensity of specific measures;

CPERF - experience and current performance.

As a result, we found out that the mutual correlation between the sub-divisional units "COMP" is with a high level of correlation with the level of decentralization of the hospital or facility $\left(\alpha_{4}=-0,01\right.$ at a $\left.p<0,05\right)$. It was a surprised result the lack of any evidence for correlation between the decision for the level of decentralization and the structure of the balanced score card system of key indicators (AGG_P, SPEC_P и DECEN_P) (Kaplan, Atkinson, 1998; Khandwalla, 2010; Milgrom, Roberts, 2015; Nagar, 2014).

\section{CONCLUSION}

In the present published results, there are proven the importance and usefulness of using the performance measurement system for increasing the advantages for the competitiveness of a strong decentralized organizational system such as it is the Bulgarian social health care system. Also, it was proven that the outer environment factors that describe the knowledge transfers costs amount, have an important significance for the scope of the decision delegation definition when a decision has to be taken. Both variables "GROWTH" and "SIZE" are in a positive correlation with the managing variable "LEVEL OF DECENTRALIZATION" $\left(\alpha_{5}=0,28\right.$ and $\alpha_{6}=0,17$ at $\left.p<0,05\right)$. The hypothesizes was proven about the connection between the level of decentralization and the mutual correlation between the sub-divisional units from the investigated Bulgarian facilities and hospitals. The economic effect from this research is based on the result that as much as there are mutual correlations between the sub-divisional units as more it increases the decentralized taking of decision costs. The Bulgarian health care managers have the practice to take suboptimal decisions without considering their impact on the next correlated sub-divisional units. In order to establish a better optimum, the top health care managers must save for themselves the rights to take their own decisions even though the strong decentralized organizational system.

\section{REFERENCE LIST}

Bouwens, J., Abernethy, M.A. (2000). The Consequences of Customization on Management Accounting System Design, Accounting, Organizations and Society, 25(3), 2000.

Christie, A.A., M.P. Joye, R.L. Watts, (1993). Decentralization of the Firm: Theory and Evidence, WP, University of Rochester,1993.

Jensen, M.C., Meckling, W.H., (1992). Specific and General Knowledge and Organizational Structure, in: Werin, L. and Wijkander, H. (Eds.) Contract Economics, Blackwell Publishers, Cambridge, 1992.

Kaplan, R.S., A.A. Atkinson, (1998). Advanced Management Accounting, Prentice Hall, Upper Saddle River, NJ, 3rd edition, 1998.

Keating, A.S., (1997). Determinants of Divisional Performance Evaluation Practices, Journal of Accounting and Economics, 24, 1997.

Khandwalla, P.N., (2010). The Effect of Different Types of Competition on the Use of Management Controls, Journal of Accounting Research, 10(2), 2010.

Milgrom, P., Roberts J., (2016). Economics, Organization and Management, Prentice-Hall, Upper-Saddle 
River, NJ 2016.

Milgrom, P., Roberts, J., (2015). Complementarities and Fit: Strategy, Structure and Organizational Change in Manufacturing, Journal of Accounting and Economics, 19, 2015.

Nagar, V., (2014). Interrelations Among a Firm's Delegation and Incentive Compensation Choices, WP, University of Michigan Business School, 2014.

Simons, R. (2017). Levels of Control, Accounting Control Systems and Business Strategy, Accounting, 4, 2017.

Petkova - Georgieva, St., (2018). Basic Problems to Solve in Strategic Controlling Implementation, annual of "Prof. Dr. Assen Zlatarov", pp. 71 - 77, v. XLVII, book 2, Burgas, Bulgaria, 2018, ISSN 2603-3976.

Todorov, M. (2018a). Recent advances in computational chemistry for identification of ligands for biological receptors: interdisciplinary aspects, Medical Science Pulse 2018 (12) 1, pp. 12-15, DOI: 10.5604/01.3001.0011.6670, ISSN: 2544-1620.

Todorov, M.(2015a) Computational tools for prediction of nuclear receptor mediated effects. East. Acad. J., 2015, 1, pp. 46-56, ISSN:2367-7384.

Terziev, V., Petkova - Georgieva, S. (2019). The performance measurment system key indicators and the determinants impact on the level of decentralization using as an example a subdivisional unit from the Bulgarian social health and care experience. // Proceedings of SOCIOINT 2019- 6th International Conference on Education, Social Sciences and Humanities 24-26 June 2019- Istanbul, Turkey, International Organization Center of Academic Research, Istanbul, Turkey, 2019, pp. 515-524, ISBN: 978-605-82433-6-1

Terziev, V., Petkova - Georgieva. (2019a). S. A research study of nonlinearity experiencing in the rate of current account deficit to the Bulgarian health and care national product. // Proceedings of SOCIOINT 2019- 6th International Conference on Education, Social Sciences and Humanities 24-26 June 2019Istanbul, Turkey, International Organization Center of Academic Research, Istanbul, Turkey, 2019, pp. 525-533, ISBN: 978-605-82433-6-1. 